\title{
繰返し載荷による鋼梁の延性破断 \\ DUCTILE FRACTURE OF STEEL BEAMS UNDER CYCLIC LOADING
}

\author{
桂大輔*, 宮澤秀明**, 桑村 仁*** \\ Daisuke KATSURA, Hideaki MIYAZAWA and Hitoshi KUWAMURA
}

\begin{abstract}
The experiment on cumulative plastic deformation capacity of steel beams up to ductile fracture under variable ductile amplitude cyclic loading was carried out. Cumulative plastic deformation capacity by constant amplitude loading could be formulated by similitude law of prefracture hysteresis. That by variable amplitude loading could be formulated by similitude law and Miner's law. That was also influenced by the order of large and small amplitudes and by deviation of maximum amplitude from average amplitude. The limit point when strength was decreased to a specified value was defined. Cumulative deformation capacity up to the limit point could be formulated by similitude law and Miner's law.
\end{abstract}

Keywords : ductile fracture, cumulative plastic deformation capacity, variable amplitude loading, similitude law of prefracture hysteresis, Miner's law 延性破断, 累積塑性変形能力, 変動振幅載荷, 破断履歴の相似則, Miner 則

\section{1.はじめに}

鋼構造建物の現状の設計では，部材の持つ破断までの累積塑性変 形能力が，設計で想定する地震動に対し十分であるかどうかの直接 的検証はなされていない.しかしながら，地震被害において鋼部材 が破断した事例は報告されており，破断までの変形能力を設計上検 討する必要があると思われる.

鋼構造梁端部絽返し載荷時の変形能力については金多, 甲津(2), 成原, 泉(3), 小川, 大熊, 中込(4)によって研究されている. 文献(2) では風外力に対応する低サイクル疲労に対して実験か行われている が，一部，延性破断が起きる 100 サイクル程度以下の絽返し数で破 断する繰返しレベルに対して実験が行われており，この繰返し数は 地震外力に対応するものと考えられる. しかし，一定振幅のみを対 象としており, 振幅の変化する載荷は対象にしていない. 文献(3) では Miner 則に基づいて変動振幅の評価を行っているが, 風外力を 想定した疲労またはクレーンガーダーの疲労破壊のような高サイク 儿疲学を対象としている. 文献(4)においても低サイクル疲労を対象 としている. このように, 地震外力に対応する延性破断する絽返し 数において, 部材の変形能力を定量的に評価した研究は少ない. 鋼部材の破断までの変形能力については，大きな変形履歴を経験
させるよりも, 小さな変形蕧歴を繰返し作用させた力が, 破断まで の累積塑性変形能力が大きいことが知られている. 桑村らは一定振 幅載荷時の累積塑性変形能力に対する変形履歴の影響を「破断履歴 の相似則」(5)にまとめている. さらに振幅が変動する变形履歴を受け る場合についても Miner 則を用いて累積塑性変形能力を評価でき る(6)ことを示している.

本研究では，延性破断をする鋼梁の変動振幅を含む繰返し載荷に よる曲げ破壊試験を行い, 振幅の大きさ以外の大振幅と小振幅の順 番など従来無視されてきた要因も考慮しつつ, 累積塑性変形能力を 評価する方法を提案するものである. さらに，延性破断が生じる時 だけでなく, 耐力があるレベルまでの低下するまでの累積塑性変形 能力に関しても予測を試みた。

表 1 素材試験結果 (SS400)

\begin{tabular}{|c|c|c|c|c|c|c|c|}
\hline 部位 & サンプル数 & $\begin{array}{c}\text { ヤング摔 } \\
\mathrm{E} \\
\left(\mathrm{kN} / \mathrm{mm}^{2}\right) \\
\end{array}$ & $\begin{array}{c}\text { 降伏点 } \\
0_{3} \\
\left(\mathrm{~N} / \mathrm{mm}^{2}\right) \\
\end{array}$ & $\begin{array}{c}\text { 引張強さ } \\
\sigma_{u} \\
\left(\mathrm{~N} / \mathrm{mm}^{3}\right) \\
\end{array}$ & $\begin{array}{c}\text { 降伏比 } \\
\text { YR }\end{array}$ & $\begin{array}{c}\text { 一様伸び } \\
\varepsilon_{u} \\
(0) \\
\end{array}$ & 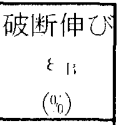 \\
\hline フランジ & 8 & 212 & 317 & 446 & 0.71 & 20.8 & 41.1 \\
\hline ウェブ & 4 & 211 & 339 & 459 & 0.74 & 15.1 & 34.8 \\
\hline 全体 & 12 & 211 & 324 & 450 & 0.72 & 18.7 & 39.0 \\
\hline
\end{tabular}

JIS5号試験片に上万。表中の值仗試験片の平均。

(1):降伏棚の值

\footnotetext{
本諭文は文献(1)を加籍修正したもので充る。

東京大学大学院丁学柔研究科建築学専攻 学術研究支援貝・工修

** (侏ゴールドクレストて修

(元 東京大学大学院建築学尃攻)

*** 東京大学大学院工学系研究科建築学専攻 教授. Ph. D.
}

Research Assistant, Dept. of Architecture, The University of Tokyo, M. Eng.

Gold Crest, M. Eng.

(Former Graduate Student, The University of Tokyo)

Prof., Dept. of Architecture, The University of Tokyo, Ph. D. 


\section{2. 試験体}

試験体はSS400 のロールル成形の H 形銅を使用した，素材試験結 果を表 1 に示す.試験片は鋼材の 1 ロット数に付きフランジ 2 筒所,

ウエブ 1 筒所から取り出し, 4 ロットの鋼材から計 12 片取った。表

8

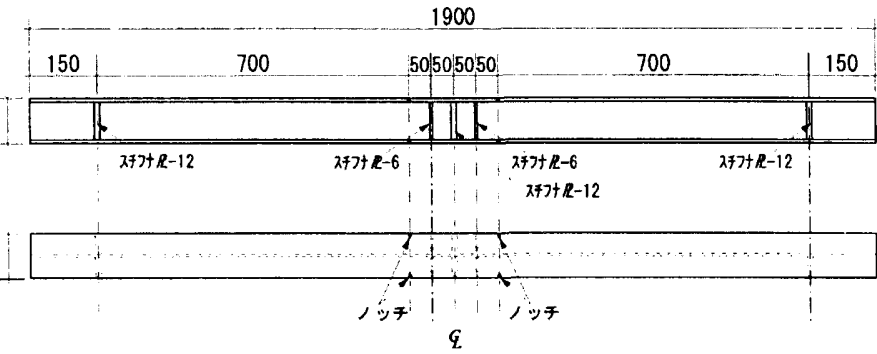

図 1 試験体形状

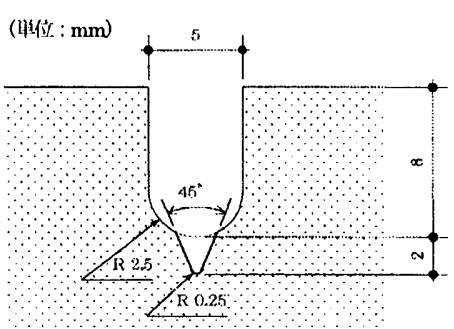

図 2 ハッチ詳細図

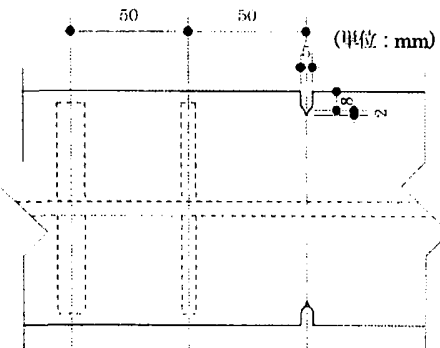

E 図3 ノッチ位置

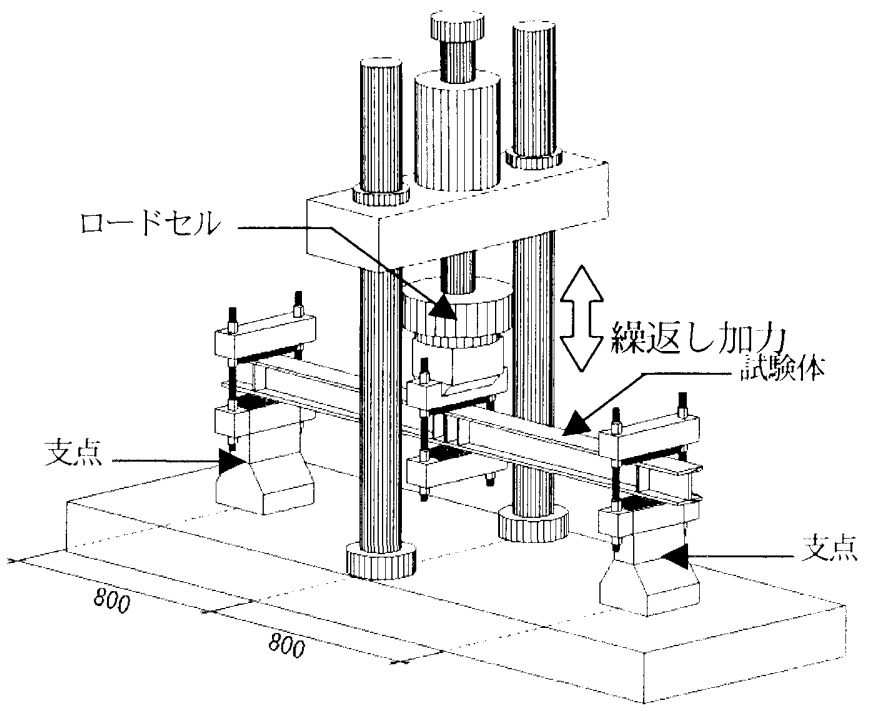

図 4 試験体設置図

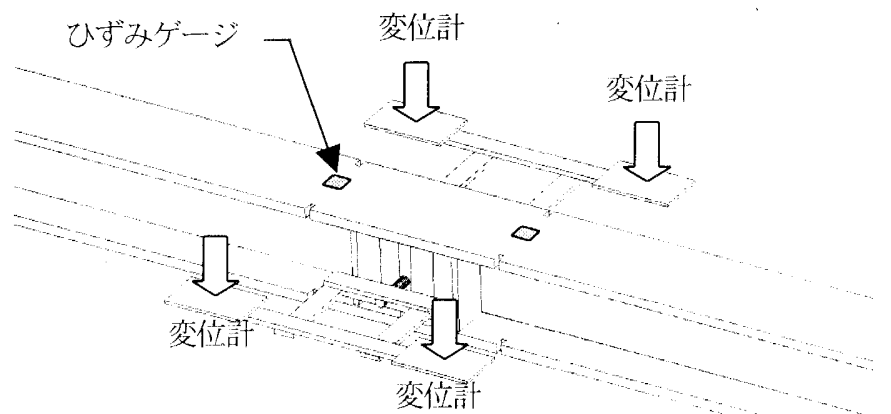

図 5 変位計による計測要領
に示したのはフランジ，ウェブ毎抢よび全体の素材試験結果の平均 值である、ひずみの計測はひず夕ゲージにて行い、ひずみゲージで は計測できない大ひずみ領域はカラー画像センサーを用いた。

試験体は図 1 に示す全長 $1900 \mathrm{~mm}$, 断面形状 H-100× $100 \times 6 \times$ 8 の 形鋼であり, 試験体中央の加力点および式験体端部の支持点 にスチフナを設けた. また, 試験体中心線から両側 $50 \mathrm{~mm}$ の位監に 局部座屈防止のためのスチフナを設けた．また，試験体中心線から 両側 $100 \mathrm{~mm}$ の位置のフランジ両端に，延性亀裂の始点となるべき ノッチをト下フランシ涑偭で計 8 ヶ所設けた。 ノッチ詳細図を図 2 に，ノッ千位置を図 3 に示す。切炊き深さ $10 \mathrm{~mm}$ ，切欠き幅 $5 \mathrm{~mm}$ とし，フランジに厈縮応力が扣わる際にも䔦口部が閉じない形状と している.

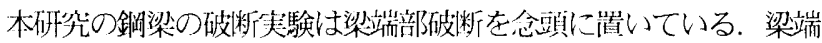
部に存在する形状的ノッチ，溶接金属や $\mathrm{HAZ}$ 部などの材質的ノッ チなどによる多㡖心力状態を人下的ノッチに置き換えた実験である，

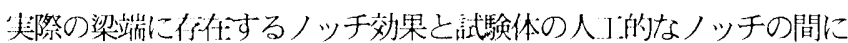

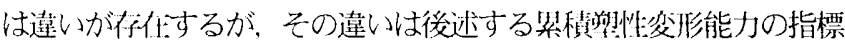

\section{表 2 試験体の載荷履歴一覧}

\begin{tabular}{|c|c|c|c|c|}
\hline 哃驗休 & 械衡方法 & $\begin{array}{c}\text { 大拢棏 } \\
\text { d1 }\end{array}$ & 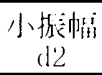 & 振幅履歴図 \\
\hline $1: 1$ & 掼调 & - & - & \\
\hline $1: 2$ & $\cdots \cdot$ 足报幅 & $30 \mathrm{~mm}^{(1)}$ & - & 区i6(a) \\
\hline $1: 3$ & 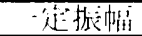 & $90 \mathrm{rmm}$ & - & $|\otimes| 6(a)$ \\
\hline $1: 4$ & 足:振幅 & $60 \mathrm{~mm}$ & - & {$[\times \mid 6(\mathrm{a})$} \\
\hline $1: 5$ & 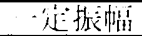 & $14 \mathrm{~mm}$ & - & $|\times| 6(a)$ \\
\hline $1: 6$ & 一是:振幅 & $20 \mathrm{~mm}$ & - & [ख]6(a) \\
\hline $1: 7$ & 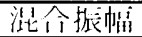 & $30 \mathrm{~mm}$ & $20 \mathrm{~mm}$ & 䘞6(b) $: n=3$ \\
\hline $1: 8$ & 韲金报帖 & $60 \mathrm{~mm}$ & $20 \mathrm{~mm}$ & $|\otimes| 6(b): n=15$ \\
\hline $1: 9$ & 洁合振幅 & $20 \mathrm{~mm}$ & $14 \mathrm{~mm}$ & $|\times| 6(b): n=3$ \\
\hline $1: 10$ & 洁全报幅 & $30 \mathrm{~mm}$ & $20 \mathrm{~mm}$ & 涩6(e) \\
\hline $1: 11$ & 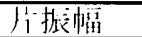 & $60 \mathrm{~mm}$ & - & |ख्|6(d) \\
\hline $1: 12$ & 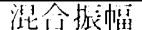 & $60 \mathrm{~mm}$ & $20 \mathrm{~mm}$ & 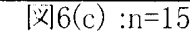 \\
\hline
\end{tabular}

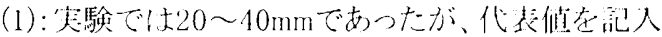

(a) 一定振幅

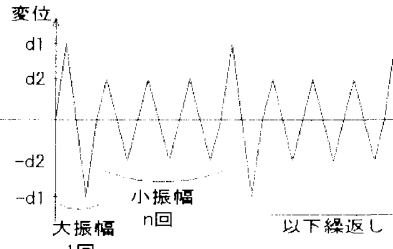

(c)混合振幅(大振幅が先)

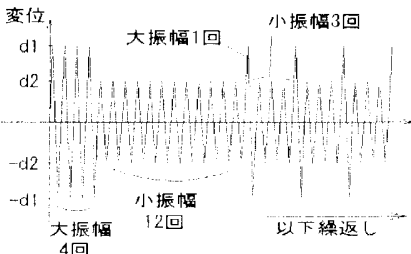

(e)混合振幅 (大振幅が先)

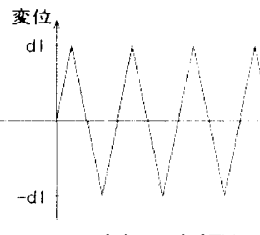

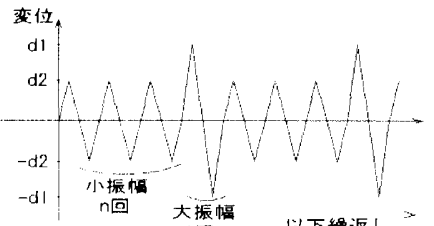

(b) 混合振幅 (小振幅が先)

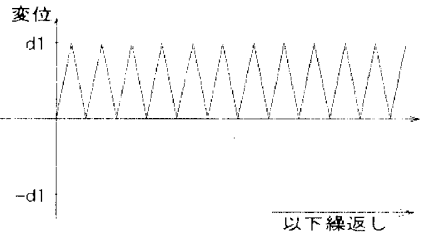

(d) 片振幅
図 6 載荷履歴のパターン 
值によって表現されると考えられるので，今回の実験ではノッチ形 状については検討を行わず，1種類のノッチ形状としている.

\section{3. 実験方法}

実験は図 4のような三点曲げ試験法により行った。試験体端部上 下を鋼製の丸棒で挟み込み，支点間隔 $1600 \mathrm{~mm}$ でローラー支持し た. 中央部も同様の丸棒で挟み込み，その部分を連続的に上下繰返 し載荷を行った. 鋼材のノッチ部分からの延性亀裂が十分進展し, 鋼材としての耐力がなくなるまで載何を行った. 載荷の制御は試験 機の変位制御により行つた.

なお，上下のローラーを鋼棒で緊結したため，端部ローラーに試 験体が固定されてしまうのを防ぐために，上下円筒鋼材と試験体の 間に隙間を設けた。

計測は加力へッドに取り付けられたロードセルによる荷重および 変位計，ひずみゲージにより行った，変位棓十による計測要領を図 5 に示す.

試験体は 12 体で載荷履歴をパラメータとして実験を行った. 試 験体の載荷履歴一覧を表 2 に, 載荷履歴のパターンを図 6 に示す. 単調載荷 1 体, 一定振幅載荷 5 体, 混合振幅載荷 5 体, 片振幅 1 体 である.このうち，混合振幅，片振幅に関しては文献 5),6)において は扱っていない，混合振幅の試験体は表 2 に示す 2 種類の振幅の載 荷を図 6(b),(c),(e)のように一定の割合で混合し載何を行った. なお， 2 種の振幅の混合割合は後に示す破断に及ぼす損傷の影響が 2 種の 振幅で同程度となるように $\mathrm{n}$ を決めた，片振幅の試験体は図 6(d)の ように振幅を片側方向のみ変位させる載荷方法を取った.

\section{4. 実験結果}

図 7 に鋼材の破壊過程の説明図を示す．載荷が進むにつれて進行 していく亀裂の状況を時間を追って a),b),c),d)の順に表現した.いず れの試験体もb)ノッチから延性亀裂が生じ，c)載荷が進むにつれて， いくつかのノッチで生じた亀裂はさらに大きなものへと進行した. やがて, フランジの側面の一方のノッチから生じている亀裂がウェ ブにまで澾するものになり，さらにd)ウェブ中央部への亀裂が進展

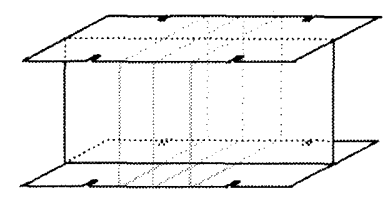

a）載荷実験開始前

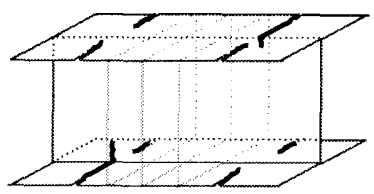

c）実験終了間際

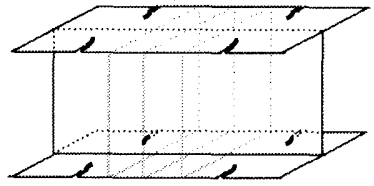

b）亀裂進行開始

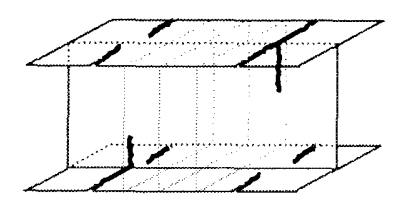

d）上フランジ断面の破断 図 7 鋼材の破壊過程の例

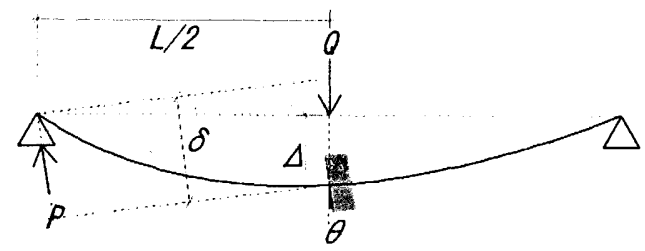

図 8 単純梁から片持ち梁への変換
した. ある試験体ではフランジ両側から進展した亀裂が連結し，い くつかの試験体ではフランジ片側から亀裂が進展しウエブを超えて 逆側のフランジまで進展しフランジ全断面に亀裂が及んだ。 フラン ジ全断面に亀裂がつながった時点で荷重が急激に減少した。いずれ の試験体においてもフランジが全断面破断する段階と荷重が急激に 減少する段階がほぼ等しいので，この時点を鋼材の延性破断とみな した.

なお, 亀裂准展の初期の段階では左右のノッチからの亀裂は同程 度に進展するが，ある程度龟裂が進展すると左右の龟裂の進展度合 いの差が大きくなっていった，そして，最終的には亀裂の進展が大 きかったほうが破断に至る．そのため中央部で梁を左右に分けて考 えると，左右の梁で変形の度合いが異なっている．結果的に破断し なかった梁の亀裂の進展具合で実験デ一夕が左右されることを防ぐ ために，図8のように，中央を載荷される単純梁を中央で左右に分 割し，中央部を固定端とする片持ち梁とみなして実験デ一夕の整理 を行った. 左右の梁の変形度合いが異なることから, 中央部分の固 定端は傾きが生じる. 片持ち梁としての荷重 $P$, 変形 $\delta$ は単純梁とし ての荷重 $Q$, 変形 $\Delta$, さらに中央部分の傾き $\theta$ を用い式(1),(2)のよう に表される.

\section{表 3 実験結果一覧}

\begin{tabular}{|c|c|c|c|c|}
\hline \multirow[b]{3}{*}{ 試験体 } & \multicolumn{3}{|c|}{ 破断までの性能 } & \multirow{3}{*}{$\begin{array}{c}\text { 限界耐力点 } \\
\text { までの性能 } \\
\text { ま } \\
\text { 累積塑性率 } \\
\eta_{p}\end{array}$} \\
\hline & 塑性率振幅 & 累積塑性率 & 修正サイクル数 & \\
\hline & $\mu_{p}$ & $\eta_{p}$ & $N_{f}$ & \\
\hline E1 & 29.7 & 29.7 & 1 & $-^{(2)}$ \\
\hline $\mathrm{E} 2$ & 2.96 & 85.9 & 29 & 46 \\
\hline E3 & 8.21 & 41.0 & 5 & $--^{(4)}$ \\
\hline E4 & 6.77 & 60.9 & 9 & 41 \\
\hline E5 & 0.57 & 380 & 665 & $-{ }^{(3)}$ \\
\hline E6 & 1.29 & 192 & 149 & 94 \\
\hline E7 & 1.66 & 148 & 89 & 78 \\
\hline E8 & 1.56 & 98.0 & 63 & $-^{(4)}$ \\
\hline E9 & 0.96 & 245 & 255 & 126 \\
\hline E10 & 1.51 & 219 & 145 & 107 \\
\hline E11 & 2.68 & 77.7 & 29 & 47 \\
\hline E12 & 1.87 & 87.9 & 47 & 64 \\
\hline
\end{tabular}

(1):7節参照. 限界耐力低下率 $\alpha=1.0$ (2): 単調載荷なので, 限界 耐力点老設定できない（3):サイクル耐力 $P_{s i}$ を定めるサイクル 塑性率 $\mu_{p i}$ よりも小さい振幅のため, 限界耐力点老設定できない。 (4): 限界耐力 $\alpha P_{P}$ まで耐力が低下-立万前に破断したので, 限界耐力点在設定できない

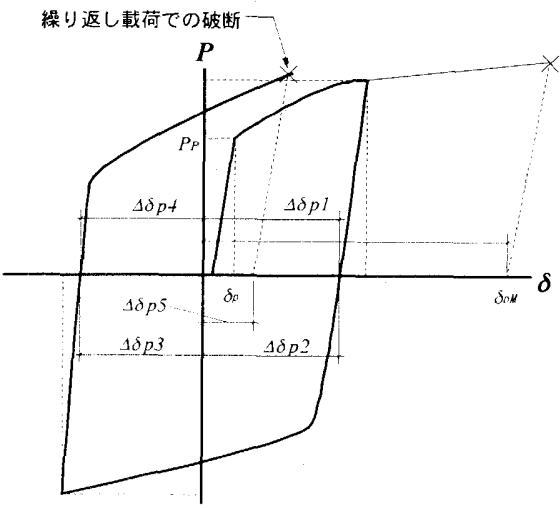

図 9 記号の説明図 
$P=\frac{Q}{2}$

$\delta=\Delta+\frac{L}{2} \theta$

実験結果の一覧を表 3 に示す．表中には破断までの値とともに 7 節で述べる一定值まで耐力があるレベルに低下するまで（限界耐力 点）の累積塑性変形能力を併記した. 本研究で用いる記号の定義は 以下の通りであり, 記号の説明図は図 9 である. 試験体の荷重 - 累 積変形関係の例を図 10 に示す。

$P_{p} \quad:$ 降伏荷重 (ゼネラルイールド法による)

$\delta_{p} \quad$ 弾性限変形 $\left(P_{p}\right.$ を初期岡性で除した $)$

$\Delta \delta_{p i} \quad$ : 各修正サイクル $(i)$ の塑性変形

$\mu_{p}=\overline{\left(\frac{\Delta \delta_{p i}}{\delta_{p}}\right)}$

: 塑性率张幅(はは平均を表す)

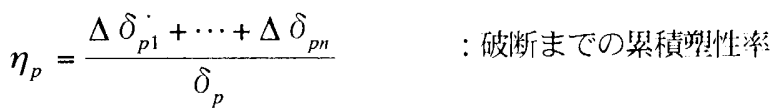

$\eta_{p M}=\frac{\delta_{p M}}{\delta_{p}}$

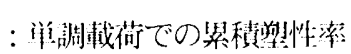

$N_{f}=\frac{\eta_{p}}{\mu_{p}}$

: 破断までの修川:サイクル数

\section{5. 一定振幅載荷試験体の考察}

「破断履歴の相似則」(ら)とは「材料や溶接の条件が罣なる鋼部材 $\mathrm{A}$

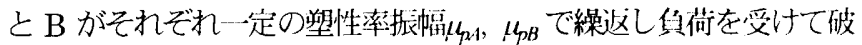
断するまでの修正サイクル数 $N_{f}$ か等しければ任意の係数 $c$ を乘じた

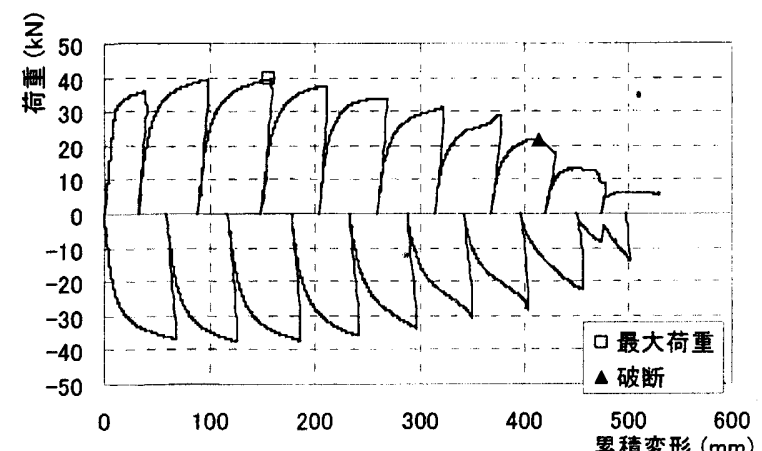

(a) 試験体E2

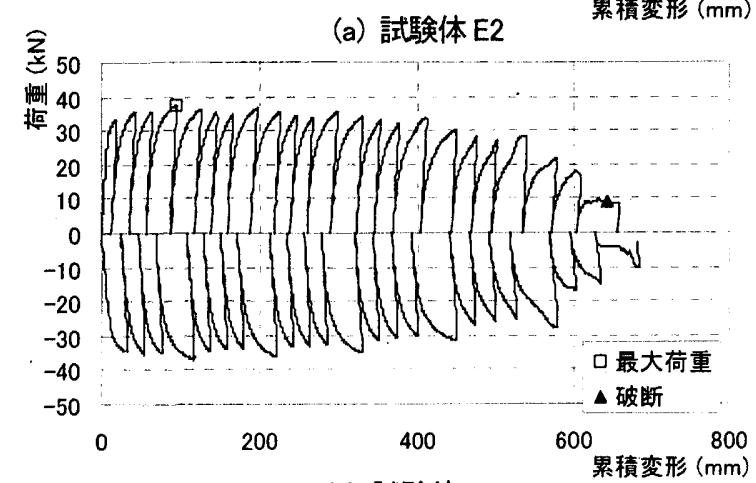

(b) 試験体 E7

図 10 荷重一累積変形関係の例
塑性率振幅 $c \mu_{P A}, c \mu_{P B}$ に対して $\mathrm{A}$ と B は等しい修正サイクル数 $N_{f}^{\prime}$ で破断する」というものである.

これは次のように言い換えることができる、「破断に至るまでの累 積塑性変形能力を材料や接合方法の影響を表す定数 $\eta_{p M}$ て除した $\eta_{p}$ $/ \eta_{p M}$ や修正サイクル数 $N_{f}$ は塑性率振幅を $\eta_{p M}$ で除した $\mu_{p} / \eta_{p M}$ だけで 決まる。

そして, 破断までの修正サイクル数 $N_{f}$, 塑性率振幅 $\iota_{0}$, 破断まで の累積塑性変形能力 $\eta_{p}$ の 3 つ値は材料や接合方法等の違いを表す 糔を用いることにより，3つのうち1つを決めることにより，残り の 2 つの值を決定することになる. 3 つの值を変換する関数は材料 や溶接などの条件にかかわらず，定となる。

上記の関数として文献(5)では式(3a),(3b)が用いられている.

表 4 破断までの実験值と予測値

\begin{tabular}{|c|c|c|c|c|c|c|c|}
\hline \multirow[t]{2}{*}{ 試験体 } & \multicolumn{3}{|l|}{ 笑験值 } & \multicolumn{2}{|c|}{ 式(3)に上万予測值 ${ }^{* 1}$} & \multicolumn{2}{|c|}{ 式(4)に上万年測值 ${ }^{*}$} \\
\hline & $\mu_{p}$ & $N_{f}$ & $\eta_{p}$ & $\eta_{p}$ & 誤差 & $\eta_{p}$ & 譔差 \\
\hline E1 & 29.7 & 1 & 29.7 & 26.0 & $12.5 \%$ & 20.6 & $30.6 \%$ \\
\hline E2 & 2.96 & 29 & 85.9 & 102 & $-18.7 \%$ & 101 & $-17.6 \%$ \\
\hline E3 & 8.21 & 5 & +1.0 & +3.5 & $-6.1 \%$ & 50.0 & $-22.0 \%$ \\
\hline E4 & 6.77 & 9 & 60.9 & 52.1 & $1+.4 \%$ & 57.1 & $6.2 \%$ \\
\hline E5 & 0.57 & 665 & 380 & 326 & $14.2 \%$ & 314 & $17.4 \%$ \\
\hline E6 & 1.29 & 149 & 192 & 186 & $3.1 \%$ & 179 & $6.8 \%$ \\
\hline
\end{tabular}

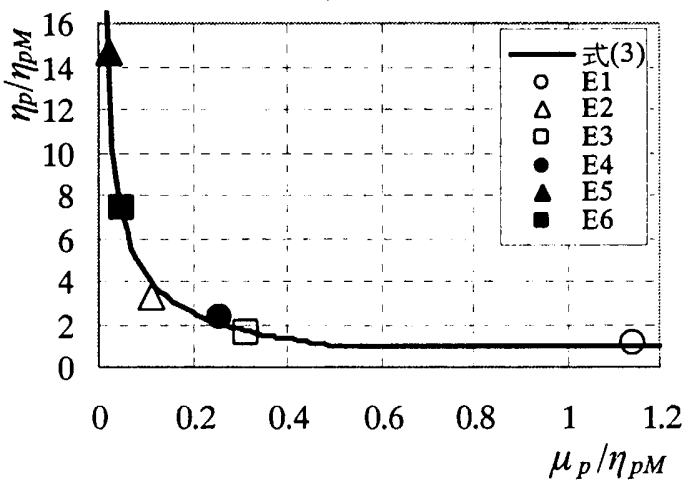

図 11 破断までの累積塑性率 $\eta_{\mathrm{p}}$ と塑性率振幅 $\mu_{\mathrm{p}}$ の関係 及び式(3)との対応 $\left(\eta_{\mathrm{pM}}=26.0\right)$

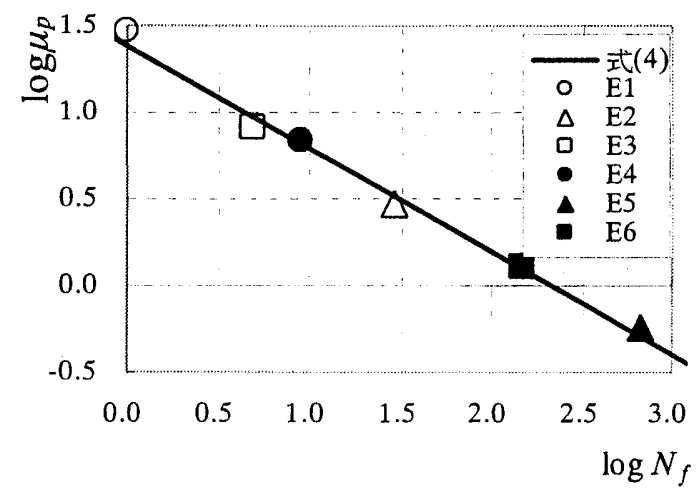

図 12 破断までの塑性率振幅 $\mu \mathrm{p}$ と修正サイクル数Nfの関係 及び式(4)との対応 $(A=2.33, k=1.69)$ 


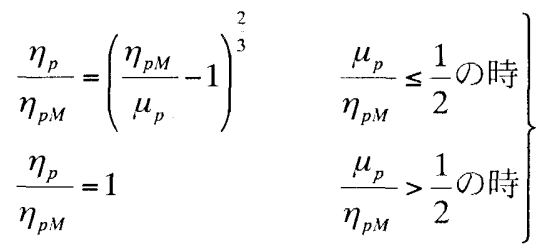

$$
\left.\begin{array}{ll}
N_{f}=\frac{\eta_{p M}}{\mu_{p}}\left(\frac{\eta_{p M}}{\mu_{p}}-1\right)^{\frac{2}{3}} & \frac{\eta_{p M}}{\mu_{p}} \geq 2 \text { の時 } \\
N_{f}=\frac{\eta_{p M}}{\mu_{p}} & \frac{\eta_{p M}}{\mu_{p}}<2 \text { の時 }
\end{array}\right\}
$$

また, 文献(7)では, 式(3a),(3b)を Manson-Coffin 式流に変形し式 (4a),(4b)を用いている. $A$ は材料や形状に依存する係数, $k$ は破断 履歴の相似則による不変量である.

$\log N_{f}=A-k \cdot \log \mu_{p}$

$\log \eta_{p}=A+(1-k) \cdot \log \mu_{p}$

単調載荷及び一定振幅載荷の試験体の実験結果の式(3)への適合 性を調べた結果を表 4 , 図 11 に示す。 $\eta_{p M}$ を一定振幅載荷の試験体 について最小自乗法により求め, $\eta_{P M}=26.0$ という值を得た。

同様に式(4)への適合性を調べた結果を表 4 , 図 12 に示す．同様 に $A, k$ を最小自乘法により求め, $A=2.33, \mathrm{k}=1.69$ を得た.

一定振幅載荷試験体に㧧いて，破断までの累積塑性変形能力の予 測誤差は単調載荷試験体を除くと最大 $22 \%$ 程度であった。

\section{6. 変動振幅載荷試験体の考察}

\section{1 試験体毎の比較}

表 2 の試験体の載荷履歴一覧及び表 5 の破断までの実験値を参照 し，載荷履歴の直接の比較ができるものを比較してみると次のよう な傾向が見られる.

\section{（1）振幅を混合させることによる影響}

混合振幅載荷の大振幅・小振幅成分之一定振幅載荷試験体之の直 接比較した.この比較が可能な混合振幅載荷試験体と一定振幅載荷 試験体の組合せは，以下のとおりである。
1) E7：E2(大振幅成分), E6(小振幅成分)
2) E8：E4(大振幅成分)，E6(小振幅成分)
3) E9：E6(大振幅成分)，E5(小振幅成分)
4) E10：E2(大振幅成分), E6(小振幅成分)
5) E12：E4(大振幅成分), E6(小振幅成分)

1)，2，3)，5)に関しては，混合振幅載荷試験体の $\eta_{p}$ の值は，対応 する一定振幅載荷 2 種の $\eta_{p}$ の間をとる. ただし, 4)は例外であった。 4)のケースは試験方法により大振幅と小振幅の内訳に違いがあるた めと思われる.

\section{（2）大振幅と小振幅の順番による影響}

大振幅と小振幅を与えた順番による影響を直接比較できるのは以 下の2つである.

1) E8(先に小振幅成分) - E12(先に大振幅成分)

2) E7(先に小振幅成分) - E10(先に大振幅成分)
1)について大振幅が先の力が $\eta_{p}$ の值は若干小さくなるが，2)につ いては逆である.

\section{（3）片振幅の影響}

片振幅載荷試験体である E11 は一一定振幅載荷試験体 E2 と振幅が ほぼ等しく, 直接比較できる. 比較すると $\eta_{p}$ の值はE11 が小さくな つた. 片振幅により変形能力が小さくなったと考えられる.

\section{2 Miner 則による評価}

疲学破壊における破断時期の予測には，一般にMiner 則が用いら れている. この予測方法は，灾力の繰返しにより損傷が累積し，限 界値に達すると破断するというものである.

損傷の累積の度合いを損傷度 $D$ で表すと，Dは式(5)で表される.

$D=\sum_{i}\left(\frac{n_{i}}{N_{i}}\right)$

ここで, 数種類の応力振幅のうち, $i$ 番目の応力振幅を仮に一定振 幅載荷したときに破断に至るサイクル数が $N_{i}$ であり, 実際にその応 力振幅が加えられたサイクル数が $n_{i}$ である. 応力振幅の種類分の和 を取り，Dが 1 に達すると破断するとしている.

この考え方を文献(6)では，応力振幅を塑性率振幅と読夕替え，サ イクル数を修正サイクル数に読み替えて，鋼構造部材の破断に適用 している.

修正サイクルで $i$ サイクル目に加えられた振幅が仮に一定振幅載 荷で加えられた場合，破断するまでの修正サイクルを $N_{f i}$ とする.

1 つの修正サイクルで加わる椇傷度は $N_{f i}$ の逆数となる．それを全 修正サイクルで和を取ったものを損傷度 $D$ とし，この值が 1 を超え た時点で破断が起こると予想する. 椇傷度 $D$ は式(6)で表される. $N_{f i}$ の導出は式(3),(4)のいずれかを用いる.

$$
D=\sum_{i}\left(\frac{1}{N_{f i}}\right)
$$

応力振幅と破断までの繰返し数の関係（S-N 曲線）を用いる疲労 破断の場合にはレンジペア法やレインフローカウンティング法が良 く用いられるが，塑性率振幅と破断までの繰返し数の関係を用いる 延性破断の場合には，どのような塑性率振幅計数法が適するかにつ

\begin{tabular}{|c|c|c|c|c|c|c|c|}
\hline \multirow[t]{3}{*}{ 試験体 } & \multicolumn{3}{|c|}{ 寒験値 } & \multicolumn{4}{|c|}{ Miner則!上万予測值 } \\
\hline & \multirow{2}{*}{$\begin{array}{c}\text { 塑性率 } \\
\text { 振幅 } \\
\mu_{p}\end{array}$} & \multirow{2}{*}{$\begin{array}{c}\text { 累積 } \\
\text { 塑性率 } \\
\eta_{n}\end{array}$} & \multirow{2}{*}{$\begin{array}{c}\text { 修正 } \\
\text { +1夕几数 } \\
N_{f}\end{array}$} & \multicolumn{2}{|c|}{ 式(3)1二⿺る } & \multicolumn{2}{|c|}{ 式(4)に上万 } \\
\hline & & & & $\eta_{p}$ & 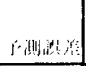 & $\eta_{p}$ & Sillits \\
\hline E1 & 29.7 & 29.7 & 1 & 26.0 & $12.5 \%$ & 20.6 & $30.6^{\%}$ \\
\hline $\mathrm{E}^{2}$ & 2.96 & 85.7 & 29 & 102 & $-19.0^{\circ}$ & 101 & $-17.9^{\circ}$ \\
\hline E3 & 8.21 & 41.0 & 5 & 43.3 & $-5.6^{0}$ & 49.9 & $-21.70_{0}$ \\
\hline E4 & 6.77 & 60.9 & 9 & 52.3 & 14.10 & 56.8 & $6.7^{0}$ \\
\hline E5 & 0.57 & 380 & 665 & 335 & 11.8 & 321 & $15.5^{0}$ \\
\hline E6 & 1.29 & 192 & 149 & 183 & $4.7 \theta_{i i}$ & 179 & $6.8^{\circ}$ \\
\hline E7 & 1.66 & 148 & 89 & 148 & $0.0^{9}$ & 145 & $2.0^{0}$ \\
\hline E8 & 1.56 & 98.0 & 63 & 123 & $-25.5^{\circ}$ & 126 & $-28.6^{\circ}$ \\
\hline E9 & 0.96 & 245 & 255 & 213 & $13.1 \%$ & 205 & $16.3 \%$ \\
\hline E10 & 1.51 & 219 & 145 & 165 & $24.7^{0}$ & 161 & $26.5 \%$ \\
\hline E11 & 2.68 & 77.7 & 29 & 105 & $35.1^{\circ 0}$ & 105 & $-35.1^{\circ}$ \\
\hline E12 & 1.87 & 87.9 & 47 & 120 & $36.5 \%$ & 120 & $-36.5^{\prime \prime}$ \\
\hline
\end{tabular}
いて検証されていない，今回は極大値と極小值の差を䜊数するレン シ法を用いた。

表 5 破断までの実験值と Miner 則による予測値の比較 
上記の検討を式(3)および式(4)を用いて得た予測值及び予測誤差 を表 5 に示す. 変動振幅載荷試験体において破断までの予測䛊差は 最大 $37 \%$ 程度であった。

\section{3 他の影響因子}

Miner 則による破断までの累積塑性変形能力の予測で予測䛊差を

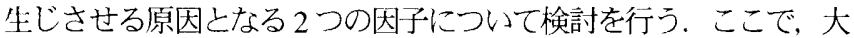
振幅と小振幅の順番による影響について「損傷時期倸数」, 振幅の差

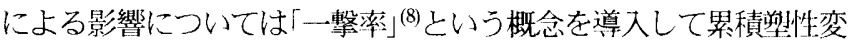
形能力の評価を行う.

\section{(1)損傷時期俰数の影響}

損傷時期係数 $\tau$ の定義を式(7)に示す.

$\tau=\frac{\sum\left\{\mu_{p i} \times\left(\begin{array}{l}\eta_{p i} \\ \eta_{p}\end{array}\right)\right\}}{\mu_{p}}$

ここで, $\mu_{p i}: i$ 修正计イクルの塑性率振幅， $\eta_{p i}: i$ 修正サイクルま での累積塑性摔である，条修Fサイクル $i$ に対して，そのサイクル

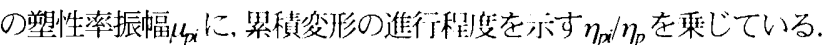
$\mu_{p i}$ の大きなサイクルが加)の終盤に集まる程 $\mu_{p i} \times\left(\eta_{p i} / \eta_{p}\right)$ は大き

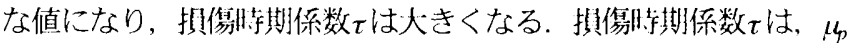

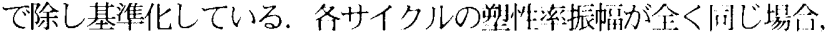

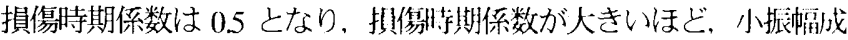

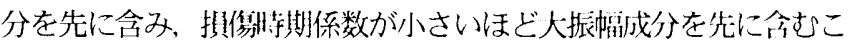
とを意味する。

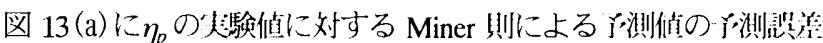

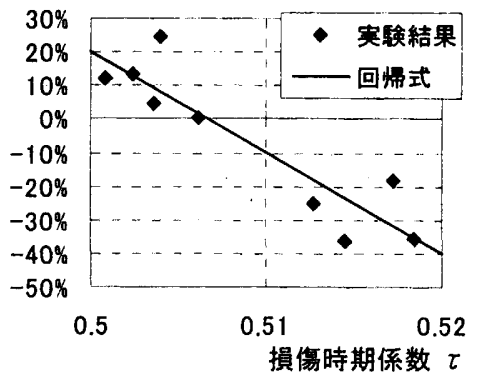

（a）損傷時期係数の影響

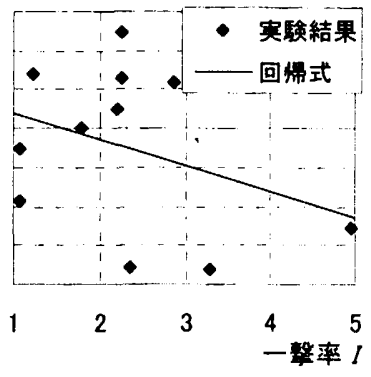

（b）一撃率の影響 図 13 損傷時期係数と一撃率の影響

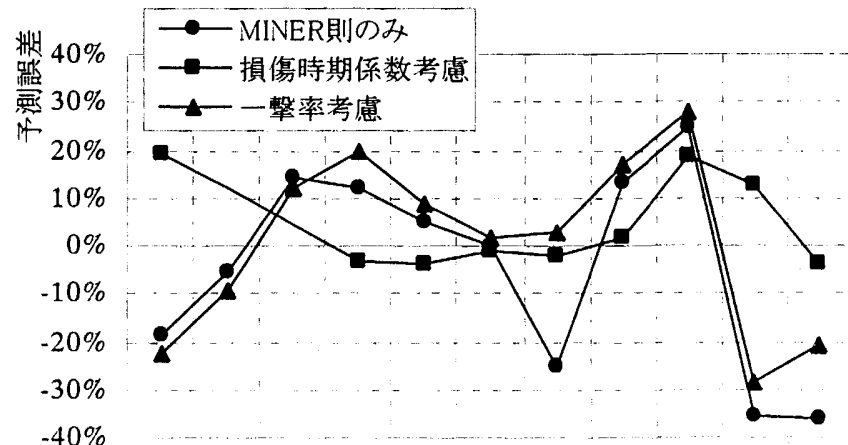

E2 E3 E4 E5 E6 E7 E8 E9 E10 E11 E12

図 14 損傷時期係数及び一撃率を考慮した 累積塑性変形能力の予測誤差
と損傷時期係数 $て$ の関係図を示す．損傷時期係数が大きくなると累 積塑性変形能力は Miner 則による予測に比べ小さくなる. 部材が比 較的小振幅の載荷を受けることにより損傷が累積した状態で大振幅 の載荷を受けると Miner 則の予測より早く破断にいたることが考え られる.

\section{(2)一撃率の影響}

一撃率 $I$ の定義を式(8)に示す.

$I=\frac{\max \left\{\mu_{p i}\right\}}{\mu_{p}}$

分里が各塑性率振幅の平均值, 分子が各塑性率振幅の最大值であ る.一撃率が大きい程，平均振幅に対して大きい振幅を含むことを 意味する. 図 13(b)に $\eta_{p}$ の実験值に対する Miner 則による予測值の 予測䛊差と一撆率の関係図を示す。一撃率が大きくなる（振幅の差 が大きい) と累栍塑性変形能力は Miner 則の予測に比べ小さくなる. 㨁下型地震による建物の忘答では平均振幅と比較し，パルス的な振

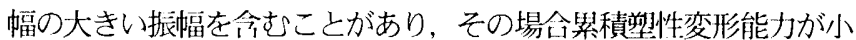
さくなる可能性が考えられる. 図 13(a)，(b)には先験值の一次四帰 線を併記した。

\section{4 他の影響因子による予測式の修正}

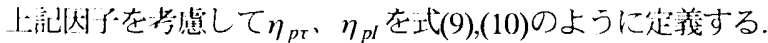

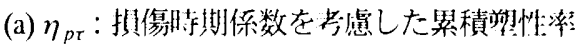

$$
\eta_{p \tau}=\left\{1+f_{\tau}(\tau)\right\} \cdot \eta_{p}=\{1+(-30.0 \times \tau+15.2)\} \times \eta_{p}
$$

(b) $\eta_{p l}:$ 一撃摔を考虑した装積朔性: 净

$$
\eta_{p I}=\left\{1+f_{I}(I)\right\} \cdot \eta_{p}=\{1+(-0.067 \times I+0.11)\} \times \eta_{p}
$$

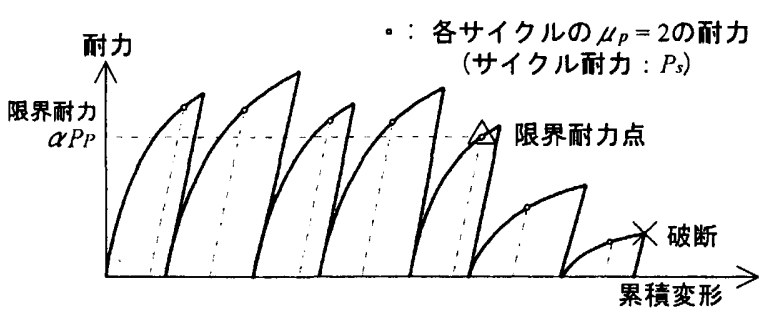

図 15 耐力限界点の定義

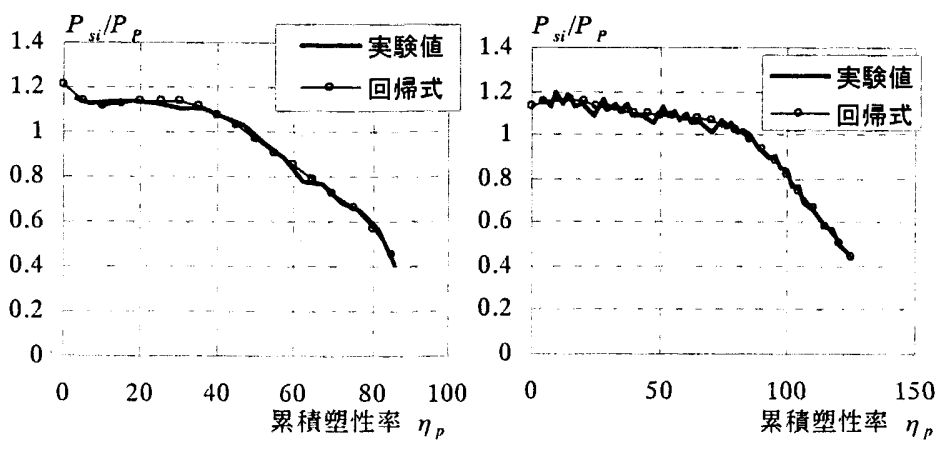

(a) 試験体 E2 (b) 試験体 E7

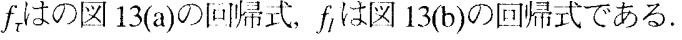

上記の方法により得た各試験体の予測䛊差を図14 に示与。 
損傷時期係数 $\tau$ ，一搫率 $I$ を考慮すると予測䛊差が小さくなる傾间 が見られる.

今回の実験結果で惊傷時期係数及び一撃率と累積塑性変形能力 の予測誤差の間には相関性があるが，決定的に有意と言えるもので はない.

\section{7. 耐力低下による延性破断変形能力の限界}

図 10 に示すとおり，脆性破断と異なり，延性破断はサイクルの 耐力が最大時と比較し相当下がってから破断をしている. 延性破断 の場合，破断する前に耐力が下がることを想定する必要があり，破 断点をそのまま設計上の限界点とすることは難しいと思われる．ま た, 最大耐力点までの累積塑性変形能力はひずみ硬化の影響を受け, 先に小振幅で後に大振幅を受ける試験体では大きいが, 先に大振幅

表 6 限界耐力点 $(\alpha=1.0)$ までの累積塑性率の実験値と予測値

\begin{tabular}{|c|c|c|c|c|c|c|c|}
\hline \multirow[b]{2}{*}{ 試験体 } & \multicolumn{3}{|c|}{ 実験值 } & \multicolumn{2}{|c|}{ 式(3)に上万予測值" } & \multicolumn{2}{|c|}{ 式(4)に上る予測值“- } \\
\hline & $\mu_{p}$ & $N_{f}$ & $\eta_{p}$ & $\eta_{p}$ & 誤差 & $\eta_{p}$ & 誤差 \\
\hline E1 & - & 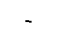 & - & - & - & - & - \\
\hline $\mathrm{E} 2$ & 3.03 & 15.2 & 46.0 & 49.6 & $-7.8 \%$ & 49.3 & $-7.2 \%$ \\
\hline E3 & - & - & - & - & - & - & - \\
\hline E4 & 6.35 & 6.50 & 41.0 & 25.5 & $37.8 \%$ & 29.4 & $28.3 \%$ \\
\hline E5 & - & - & - & - & - & - & - \\
\hline E6 & 1.05 & 90 & 94 & 110 & $-17.0 \%$ & 104 & $-10.6 \%$ \\
\hline
\end{tabular}

誤差は貸值が危険側である ${ }^{*} 1: \eta_{p M}=17.5 * 2: A=2.03, k=1.70$ E1は単調載荷, E3は限界耐力まで低下寸る前に破断, E5は振幅が小さいため，限界耐力設定できない

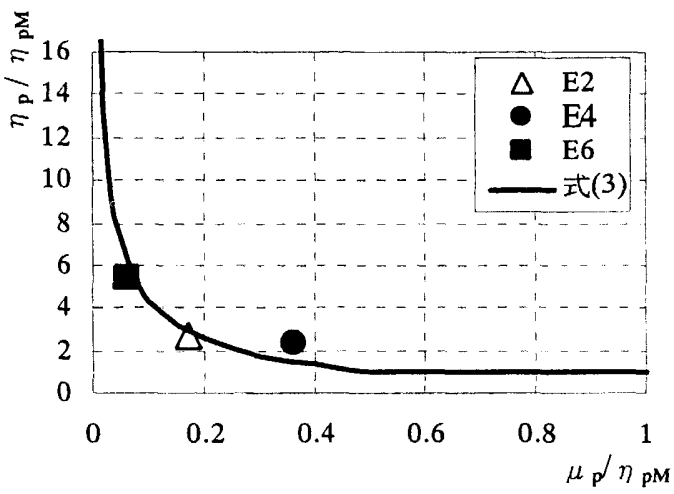

図 17 限界耐力点 $(\alpha=1.0)$ までの累積塑性率 $\eta_{\mathrm{p}}$ と 塑性率振幅 $\mu_{\mathrm{p}}$ の関係及び式(3)との対応 $\left(\eta_{\mathrm{pM}}=17.5\right)$

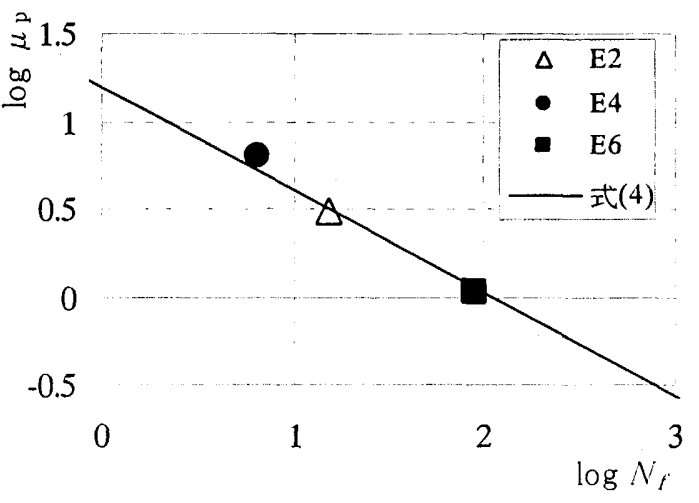

図 18 限界耐力点 $(\alpha=1.0)$ までの塑性率振幅 $\mu_{\mathrm{p}}$, 修正サイク ル数 $N_{f}$ の関係及び式(4)との対応 $(\mathrm{A}=2.03, k=1.70)$
で後に小振幅を受ける試験体では小さい，このため，異なる振幅履 歴載荷を受ける部材の場合, 最大附力点までの累積塑性変形能力を そのまま設計上の限界点とすることはできない，また，耐力が徐々 に減少していくので，よく使用されるバイリニアや完全弾塑性など の履歴則に当てはめると, 耐力が減少してきている段階では過大評 価となってしまう. そこで図 15 のように, 耐力の減少考考慮に入 れた延性破断の限界点を定義する。サイクルの耐力があるレベルま で低下した点（図 15 の）までを，延性破断する部材に期待でき る累積塑性変形能力とし，この点を限界耐力点と定義する.

また, 基準となるサイクルの耐力は同様の累積塑性変形を受けて いても，小振幅と大振幅のサイクルではひずみ硬化の影響で，大振

表 7 限界耐力低下率 $\alpha$ 毎の限界耐力点までの累積塑

性変形能力の実験値，予測值および予測誤差

\begin{tabular}{|c|c|c|c|c|c|c|c|c|}
\hline 験体 & $\eta_{p}$ & $a=1$ & $=0.95$ & $a=0.9$ & $a=0.85$ & $\mathrm{a}=0.8$ & $a=0.75$ & $a=0.7$ \\
\hline E1 & & - & & - & - & - & - & \\
\hline \multirow{3}{*}{ E2 } & \multirow{3}{*}{$\begin{array}{c}\text { 䨋駛値 } \\
\text { 予測値 } \\
\text { 誤差 }\end{array}$} & 46 & 51 & 55 & 59 & 64 & 68 & 74 \\
\hline & & 48.5 & 54.0 & 58.7 & 57.8 & 62.7 & 67.1 & 72.9 \\
\hline & & $-5.4 \%$ & $-5.9 \%$ & $-6.7 \%$ & $2.1 \%$ & $2.1 \%$ & $1.3 \%$ & $1.4 \%$ \\
\hline E3 & & ${ }^{*} 1$ & ${ }^{* 1}$ & ${ }^{*} 1$ & ${ }^{*} 1$ & ${ }^{* 1}$ & $* 1$ & $* 1$ \\
\hline \multirow{3}{*}{ E4 } & 奉験値 & 41 & 43 & 45 & & & & \multirow{3}{*}{${ }^{*} *$} \\
\hline & 予測値 & 30.4 & 34.5 & 38.0 & & & & \\
\hline & 誤差 & $25.8 \%$ & $19.7 \%$ & $15.6 \%$ & & & & \\
\hline E5 & & ${ }^{* 2}$ & ${ }^{*} 2$ & ${ }^{*} 2$ & ${ }^{*} 2$ & $*_{2}$ & $* 2$ & $* 2$ \\
\hline \multirow{3}{*}{ E6 } & \multirow{3}{*}{$\begin{array}{l}\text { 実験値 } \\
\text { 予測値 } \\
\text { 誤差 }\end{array}$} & 94 & 105 & 115 & 125 & 134 & 143 & 151 \\
\hline & & 115.0 & 129.8 & 142.4 & 142.0 & 154.8 & 166.3 & 179.8 \\
\hline & & $-22.4 \%$ & $-23.6 \%$ & $-23.8 \%$ & $-13.6 \%$ & $-15.5 \%$ & $-16.3 \%$ & $-19.1 \%$ \\
\hline \multirow{3}{*}{ E7 } & 䨍験值 & 78 & 87 & 95 & 103 & 109 & 115 & 120 \\
\hline & 予測値 & 82.1 & 91.9 & 95.9 & 94.8 & 100.5 & 107.8 & 117.2 \\
\hline & 誤差 & $-5.2 \%$ & $-5.7 \%$ & $-1.0 \%$ & $7.9 \%$ & $7.8 \%$ & $6.2 \%$ & $2.3 \%$ \\
\hline E8 & & $* 1$ & ${ }^{*} 1$ & ${ }^{*} 1$ & ${ }^{*} 1$ & ${ }^{* 1}$ & ${ }^{* 1}$ & ${ }^{*} 1$ \\
\hline \multirow{3}{*}{ E9 } & 実験値 & 126 & 133 & 140 & 147 & 153 & 160 & 166 \\
\hline & \multirow{2}{*}{$\begin{array}{c}\text { 予测値 } \\
\text { 誤差 }\end{array}$} & 115.3 & 128.2 & 137.6 & 134.9 & 145.3 & 153.5 & 164.7 \\
\hline & & $8.5 \%$ & $3.6 \%$ & $1.7 \%$ & $8.2 \%$ & $5.0 \%$ & $4.1 \%$ & $0.8 \%$ \\
\hline \multirow{3}{*}{ E10 } & \multirow{3}{*}{$\begin{array}{c}\text { 䨋験值 } \\
\text { 予测㖽 } \\
\text { 誤差 }\end{array}$} & 107 & 121 & 132 & 141 & 150 & 157 & 163 \\
\hline & & 87.4 & 98.7 & 106.0 & 104.6 & 111.3 & 120.3 & 129.0 \\
\hline & & $18.3 \%$ & $18.5 \%$ & $19.7 \%$ & $25.8 \%$ & $25.8 \%$ & $23.4 \%$ & $20.9 \%$ \\
\hline \multirow{3}{*}{ E11 } & 雵験値 & 47 & 53 & 58 & 62 & 67 & 70 & \multirow{3}{*}{${ }^{*} 1$} \\
\hline & 予測値 & 50.5 & 57.1 & 62.7 & 61.4 & 67.3 & 72.48 & \\
\hline & 誤差 & $-7.4 \%$ & $-7.7 \%$ & $-8.0 \%$ & $0.9 \%$ & $-0.5 \%$ & -0.035 & \\
\hline \multirow{3}{*}{ E12 } & 実験値 & 64 & 70 & 73 & 76 & 79 & 81 & 84 \\
\hline & \multirow{2}{*}{$\begin{array}{l}\text { 予測値 } \\
\text { 誤差 }\end{array}$} & 46.6 & 56.5 & 64.7 & 62.8 & 71.1 & 78.0 & 85.9 \\
\hline & & $27.2 \%$ & $19.3 \%$ & $11.3 \%$ & $17.3 \%$ & $10.0 \%$ & $3.7 \%$ & $-2.2 \%$ \\
\hline & & 7. & 18. & 19.5 & 19.3 & 20.2 & 21.0 & 7 \\
\hline
\end{tabular}

予測値はMiner則および式(3)による $\eta_{p}$ 予測值

*1 : 限界耐力まで耐力減少する前に破断した。

*2：塑性振幅が小さいので，限界耐力を設定できない。

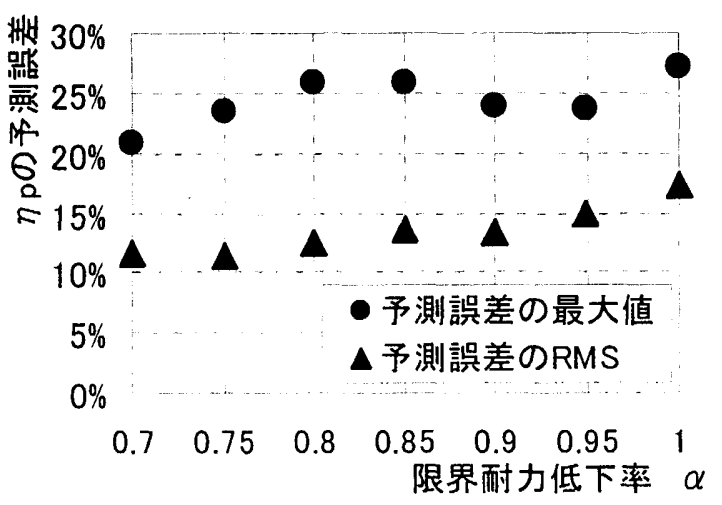

図 19 限界耐力低下率 $\alpha$ 毎の限界耐力点までの累積 塑性変形能力の予測誤差 
幅の方か酒的力が大きくなるので耐力の比較が難しい．振幅の大きさ にかかわらず耐力を比較することを可能するため, サイクル塑性率 $\mu_{p i}$ が 2 の時の耐力をサイクル耐力 $P_{\mathrm{s}}$ 亡定義し， $P_{s i}$ を比較すること にする. なお, $\mu_{p i}=2$ というのは 2 サイクル目以降のバウシンガー効 果を受けた履歴曲線が 1 サイクル目のスケルトン曲線より遅れて耐 力が増加するが, $\mu_{p i}=2$ 程度のところでスケルトン曲線とバウシンカ 一曲線が同程度の耐力となることから決めた。

図 16 にサイクル耐力 $P_{s i}$ の変化の一例を示している。いずれの試 験体も載荷の初期はあまり耐力の減少は見られないが，その後而力 の減少の割合が大きくなっている. また，グラフは凸凹しているの は上向き，下向き加力を交互に繰り返しているため，上向き，下向 き加力側で同程度の塑性変形をしていないためであると思われる.

しかしこの凸凹があると $P_{S i}$ が一定值を下回った時の累積塑性変形 倍率を定義しにくいので，灰色の曲線のように奏験值に対し 3 次か

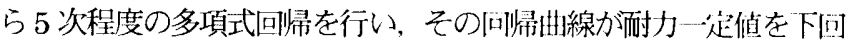
る時の耐力減少による延性破断の限界点（限界耐力点）とした。 な お，試験体 E5 に関しては基蕉となる $\mu_{p i}$ を下问る小振幅で塑性変形 履歴を受けており，試験体 $\mathrm{E} 3, \mathrm{E} 8$ は耐力が低ト寸る解に破断してい るので, この方法では評侀できない.

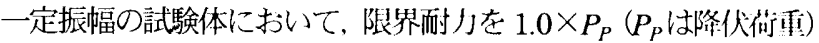
とし，サイクル耐力 $P_{\mathrm{s}}$ か限界耐ノを下回った器を限鱼耐力器とし， 「破断履歴の相似則」および Miner 則により限界耐力点までの算積

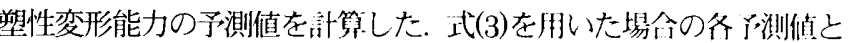
予測䛊差を表 6 に，実験值と予測刑線の関係を网 17 に，式(4)を用

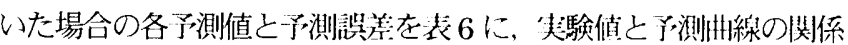
を図 18 に示す. ここで, $\eta_{p M}=17.5, A=2.03, k=1.70$ という佔を肺い

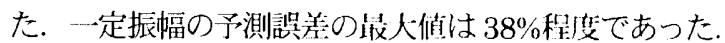

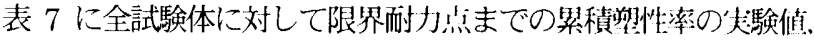
式(3)および Miner 則を用いた予測值抽よび予测譙在在限界耐抵 下率 $\alpha$ が 0.7 から 1 までについて示した. 図 19 に限界酎点まで の累積塑性摔 $\eta_{p}$ 予測值の誤差の RMS（平均自乘根）值及び地大值 を限界耐力低下率 $\alpha$ が 0.7 から 1 までについて示している. 限界耐 力低下率 $\alpha$ は限界耐力を決好際に $P_{P}$ に乗ずる值で，限界耐力は $\alpha P P$ で表される. $\alpha$ が 0.7 から 1 まで変化しても予測誤差はあまり 変動せず, 最大 $27 \%$ 程度であった. 建物の設計者がごこまで耐力の 低下を許容するかにより, 限界耐力低下率 $\alpha$ を変化させても予湘精 度にはあまり影響を及ぼさないことがわかる．このことから、表 3 および表 6 では $\alpha=1.0$ を代表の値とした。

\section{8. まとめ}

延性破断する鋼部材が変動振幅載荷を受けた時の累積塑性変形能 力について調べた. 変形㠅歴をパラメータとして H 形銅梁の繰返し 載荷による曲げ破壊試験を行った. その結果, 以下の知見をを得た。

（1）鋼部材に一定振幅載荷を行い，延性破断したときの破断までの 累積塑性変形能力は「破断履歴の相似則」を用いて定式化することが できた. 一定振幅試験体の破断までの累積塑性変形能力 $\eta_{p}$ の予測䛊 差は最大 $22 \%$ 程度であった。

（2）銓部材に変動振幅載荷を行い延性破断したときの破断までの 累積塑性変形能力は破断智歴の相似則」および Miner 則を用いて 定式化することができた．変動振幅試験体も含めての破断までの累
積塑性変形能力予測誤差は最大 $37 \%$ 程度であった

（3）変動振幅載何においては, 累積塑性変形能力については大振幅 と小振幅の順番による影響（椇傷時期係数）と振幅の差による影響 (一撃率) があるが決定的に有意と言えるものではない.

（4）延性破断する鋼部材に期待できる累積塑性変形能力の限界点 として，耐力があるレベルに低下した点である限界耐力点を定義し た。限界耐力点までの累積塑性変形能力も「破断履歴の相似則」およ びMiner 則を用いて定式化することができ, 累積塑性変形能力の予 測䛊差は一定振幅試験で「破断履歴の相似則」を用いて最大 $38 \%$ 程 度, 変動振幅試験体も含めて「破断履楚の相似則」とMiner 則を用い て $27 \%$ 程住であった。

\section{謝辞}

本研究にあたり文部科学省科学研究清補助金基艋研究 物の口バスト性に関する性能マトリックスの研究』（研究代表者：桑村 仁） の補助を受けた，夷験に当たのては，東京大学学生余良舁考（現日建設計） の協力を得た。

\section{参考文献}

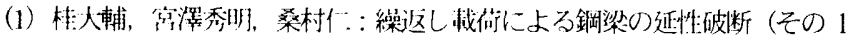

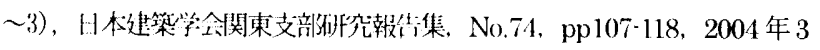
月

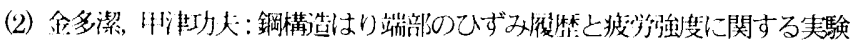

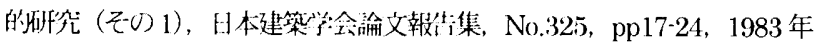
3 月

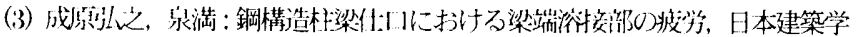
会構造系論文集，No.508，pp111-117，1998 作6月

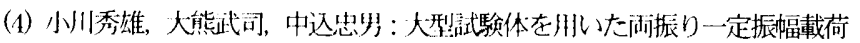

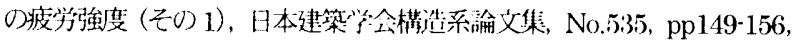
2000 年 9 月

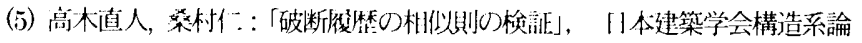
文集, No.548, pp 139-146,2001 年10月

（6）一于康生，桑村仁：鉄骨の脆性破断に及ぼす繰返し咨位振幅の影響一鉄骨 破断に関する研究 その 3 -, 日本建築学会構造系論文集, No.534, pp145-151，2000年 8 月

（7）桑村仁：「破断履歷の相似則」のマンソン-コフィン式による検証，日本建 築学会関東支部研究報告集, No.73, pp93-96, 2003 年 3 月

（8）高木直人，桑村仁：而力劣化在伴う擬似脆性破壞に及ぼす变形履歴の影響, 日本建築学会関東支部研究報告集, No.70, pp93-96,2000 年 3 月

（2004年 6 月10日原稿受埋，2004年10月22日採用決定 